\title{
Erratum: Corporate life cycle and dividend payout: A panel data analysis of companies in an emerging market
}

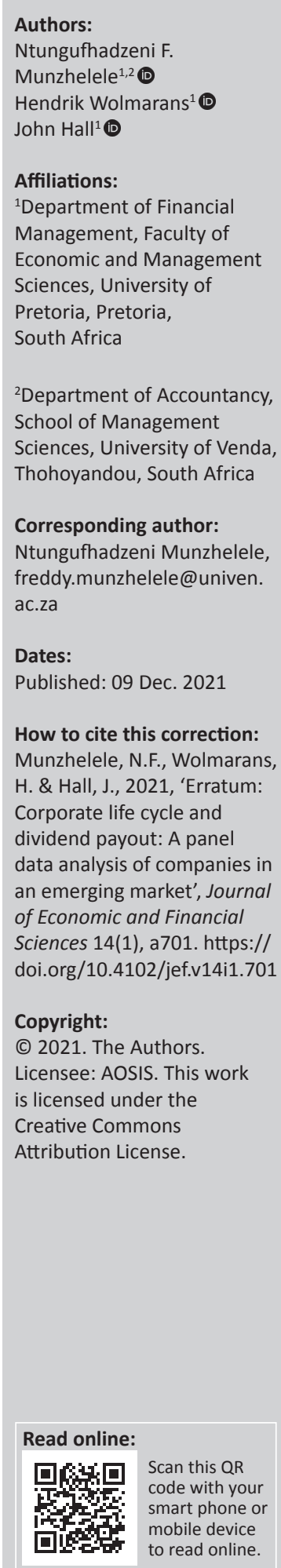

Published: 09 Dec. 2021

How to cite this correction: Munzhelele, N.F., Wolmarans, H. \& Hall, J., 2021, 'Erratum: Corporate life cycle and dividend payout: A panel data analysis of companies in an emerging market', Journal of Economic and Financia Sciences 14(1), a701. https:// doi.org/10.4102/jef.v14i1.701

\section{Copyright:}

(C) 2021. The Authors. Licensee: AOSIS. This work is licensed under the Creative Commons Attribution License.

In the version of this article initially published, Munzhelele, N.F., Wolmarans, H. \& Hall, J., 2021, 'Corporate life cycle and dividend payout: A panel data analysis of companies in an emerging market', Journal of Economic and Financial Sciences 14(1), a617. https://doi.org/10.4102/jef. v14i1.617, the article section was given incorrectly. The correct section should be Original Research instead of Review Article.

This correction does not alter the study's findings of significance or overall interpretation of the study's results. The publisher apologises for any inconvenience caused. 


\section{Corporate life cycle and dividend payout: A panel data analysis of companies in an emerging market}

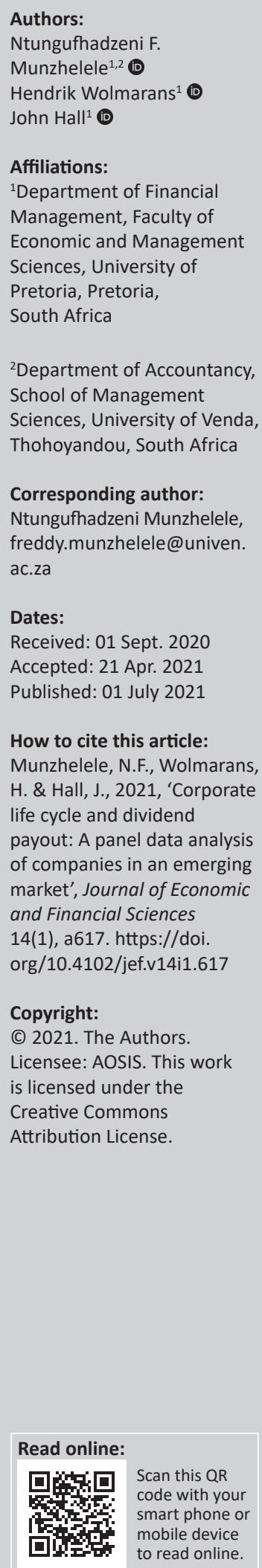

Background: The dividend payout policy remains one of the key functional areas of corporate finance because it is through receipt of dividends that shareholders can share in the profits of their investments. Amongst the dividend payout theories that have been developed over the decades, the life-cycle hypothesis has received little attention in research.

Aim: The aim of this study was to test the dividend life-cycle hypothesis in the South African contex.

Motivation for the study: Justification for this study in the context of South Africa is that there is minimal research in this regard in emerging economies. South Africa presents a good platform for this research because it is amongst the highly regarded emerging markets and this has been confirmed by its representation in Brazil, Russia, India, China and South Africa (BRICS) countries. Hence, results in this regard would shed some light in the form of a relative representation of overall emerging markets trend.

Research approach/design and method: A panel data of 119 Johannesburg Stock Exchange (JSE) listed sample companies were used to test the hypothesis during the period 2006-2015. A combination of basic and dynamic panel data estimators was used to analyse the data.

Main findings: The study finds that the dividend life-cycle hypothesis is prevalent amongst South African companies. Specifically, it was observed that the considered companies pursuing growth projects paid less dividends. Furthermore, the growth companies have shown to be more aggressive in their pursuit for growth and hence are able to create more value for shareholders than value for companies.

Managerial implications: Financial managers will be afforded with enhanced decision alternatives in respect of their fiduciary duties towards the shareholders in respect of maximising value.

Conclusion: These results provide a mirror image of those of the developed markets and a good context for future research in the same area in an emerging economy setting.

Keywords: life-cycle hypothesis; dividend payout; emerging market; growth companies; value companies.

\section{Introduction}

The dividend payout policy remains one of the most relevant functional areas and researched topics in finance. The reason for this phenomenon is that it is a puzzle with many pieces that do not necessarily fit each other (Marsh \& Merton 1987). Furthermore, through receipt of dividends, shareholders are at least able to measure returns on their investments (Erasmus 2013). Recently, there has been a marked increase in corporate scandals, risk and failures, which largely result from managements' failure to adhere to the best practices of risk management and corporate governance (Nworji, Adebayo \& David 2011; Rajagopalan \& Zhang 2009; Rossouw \& Styan 2019). These management failures have resulted in shareholders keeping their eyes closer to their investments more than ever before. Surely, the spate of these corporate problems makes one wonder if similar events may befall in the near future. With the dividend payout policy being one of the key decision areas in corporate finance, it follows that it will continue to attract debates and research interests.

Whilst the dividends payout policies have been extensively researched, there are still unanswered questions pertaining to some of the pertinent nuances regarding this phenomenon. Most studies have been conducted in the developed economies where seminal work and theories such as the dividend relevance (Lintner 1956), Miller and Modigliani (1961), life-cycle hypothesis 
(Mueller 1972), agency theory (Jensen \& Meckling 1976), signalling theory (Bhattacharya 1979; John \& Williams 1985; Miller \& Rock 1985), residual theory (Myers 1984), catering theory (Baker \& Wurgler 2004) originate from. Very little, if any, is known on how some of these theories are relevant in emerging markets such as South Africa. Life-cycle theory is one such theory that is central to this study. It is in this context that life-cycle hypothesis is a theoretical foundation upon which this study is based.

In simple terms, life-cycle hypothesis proposes that a company goes through stages in its life cycle and this impacts both its strategic and operational decisions. For example, new or young companies, which are usually smaller and less profitable, find it difficult to survive for several reasons. One of the obvious reasons is that new companies are usually financially constrained as they have lower internal liquidity and face higher external financing costs, which derive from market imperfections, higher agency and information asymmetries costs (Ascioglu, Hegde \& McDermott 2008). Within this realm, the company must develop its products and/or services market and position itself strategically. Upon passing this stage, a company then enters the growth stage. In this stage, the company maximises investment opportunities, reaches out to potential clients, improves production, marketing and strategic business positioning (Flavin \& O'Connor 2017). The earnings are volatile and low and payment of dividends is not a priority. The next stage is maturity wherein a company stabilises its market position, relaxes growth and investment pursuance, has relatively good internal funds and enhanced access to external finance and hence lower cost of finance and high earnings, which may be paid as dividends. A few studies provide evidence on the prevalence of dividend life-cycle hypothesis at the developed markets. Notably, Brockman and Unlu (2011), Coulton and Ruddock (2011) and Banyi and Kahle (2014) find a close relationship between the decision to pay dividends and proportion of retained earnings to total capital. Furthermore, Fama and French (2001), Grullon, Michaely and Swaminathan (2002), Grullon et al. (2005) and DeAngelo, DeAngelo and Stulz (2006) noticed a high fraction of companies that pay dividends when retained earnings constitute a significant portion of total earnings or total assets. Flavin and O'Connor (2017) and Bhattacharya, Chang and Li (2019) examined the relationship between payout policy and life- cycle hypothesis and found that dividends payouts increase with life cycle stages until peaking at maturity.

Accordingly, the objective of this study is to test the dividend life-cycle hypothesis in the South African setting being the emerging economy, that is, to test prevalence of the hypothesis.

There is justification for this study in the context of South Africa because there is minimal research in this regard in emerging economies. South Africa presents a good platform for this research because it is amongst the highly regarded emerging markets and this has been confirmed by its inclusion in Brazil, Russia, India, China and South Africa (BRICS) countries. The results of this study will confirm whether the South African setting mirrors those of the developed economies. Either way, results of this study will afford managers with enhanced decision alternatives in respect of their fiduciary duties towards the shareholders. Furthermore, the same would aid in advancing the life-cycle hypothesis debate in as far as the dividends payout is concerned.

The remainder of the study consists of the following sections in the given order:

- literature review

- preliminary methodology matters

- research design and methodology

- results and discussion

- conclusion, implications and suggestions for future research.

\section{Literature review}

Fama and French (2001) studied companies' propensity to pay dividends. They identified three factors that affect companies' decisions to pay dividends, namely profitability, investment opportunities and company size. Specifically, they note that larger and more profitable companies are more likely to pay dividends and companies with more investment opportunities are less likely to pay dividends. This phenomenon is consistent with companies going through maturity and growth stages, respectively, in their life cycles. Grullon et al.'s (2002) contribution is consistent with the findings of Fama and French (2001). Specifically, they conclude that systematic risk of dividend-increasing companies declines significantly, which in turn results in a decline in the cost of capital by, relatively, the same margin. Grullon et al. (2002) conceded that the potential for overinvestment is high during the company's life cycle, particularly at maturity stage. This means that, at maturity stage, the company earns large amounts in free cash flow and managers may be tempted to invest it even if it is not necessary (overinvestment) to maintain or increase resources under their control.

DeAngelo et al. (2006) studied the payout policy together with earned or contributed capital mix to test the life-cycle hypothesis. Their results are consistent with those of Fama and French (2001), Grullon et al. (2002) and Grullon et al. (2005). Explicitly, the authors establish that a fraction of listed industrial companies that pay dividends is high when retained earnings constitute a significant portion of total equity or total assets. They note on the other hand that the fraction of companies that pay dividends is low or close to zero when large portion of equity is contributed and earned. Brockman and Unlu (2011), Coulton and Ruddock (2011) and Banyi and Kahle (2014) also discovered evidence consistent with dividend life-cycle hypothesis, precisely the noticeable relationship between the decision to pay dividends and the proportion of retained earnings to total capital. Banyi and 
Kahle (2014) provided a close analysis of the association between retained earnings as ratio of total assets (RETA) and the propensity to pay dividends. They report that over a very prolonged period (39 years), there is a positive correlation between RETA, profitability, size and propensity to pay dividends, although the relationship weakens over time.

Flavin and O'Connor (2017) studied the relationship between dividend policy and life-cycle hypothesis in a low disclosure regime where companies use dividends to build capital market reputation for external investors. They find that dividend payouts increase along the companies' life cycle stages until peaking at maturity stage. Then, contrary to cases at open or high disclosure regimes, they note that companies with larger growth opportunities pay larger dividends. They consistently observe that companies at different life stages engage in reputation-building behaviour. In relatively similar study, Bhattacharya et al. (2019) documented that mature companies are likely to pay dividends. They then observe and document that life cycle changes have a significant impact on companies' payout decisions. This is some evidence that mature companies are most likely to increase or decrease dividends during transition amongst life cycle stages.

\section{Preliminary methodology matters: Units of analysis}

The outline of the given introduction and literature review has prompted a review of the distinction between value and growth companies. The main purpose of this study is to test whether South African value companies consistently pay a higher percentage of their earnings as dividends, have lower growth rates and do not pursue investments aggressively as do growth companies. In other words, the payment of dividends may have a correlation with the company's life stages, for example, at new, growth or mature stages, thus the need for the test of dividend life-cycle hypothesis. Several studies including Fama and Babiak (1968), Ahmed and Yavid (2008), Leary and Michaely (2011), Hu and Chen (2012) and Viviers, Firer and Muller (2013) tapped into the smoothing pattern of dividends thereby testing whether the phenomenon is the same between small and large companies and found that the smoothing pattern is more prevalent amongst large companies. Consequently, Crowther, Davies and Cooper (1998), Fama and French (2001), De Mortanges and Van Riel (2003) and DeAngelo et al. (2006) observed that larger and more profitable companies can pay and sustain dividends easily than other companies.

The issue of sustaining payment of dividends is crucial to an extent that potential shareholders who would survive on dividend receipts will be interested in consistent dividendpaying companies as opposed to those preferring reinvestments of earnings. A company's dividend payment consistency and payout ratio are influenced by its stock of growth options, profitability, size and age (see Leary \& Michaely 2011). Mature companies, which Barclay and
Smith (2005) and Anda et al. (2005) defined as value companies, tend to be large and profitable companies with limited growth options. Consequently, mature companies do not aggressively pursue investment opportunities and they generate substantial free cash flows, which increase their agency costs of overinvestment (Myers \& Majluf 1984; Harris \& Raviv 1991). To minimise these costs, mature firms consistently pay a significant portion of their earnings as dividends (Barclay \& Smith 2005). This distribution policy of mature companies leads to a consistently higher payout ratio. The companies that do not exhibit these features are then classified as 'growth'. The distinction of companies in this regard is relative to an extent that a company that has been in existence for many decades or even a century may still be classified as 'growth', that is, if it does not possess attributes of 'value' company. Thus, this study has adopted the basis of the distinction between value and growth companies as outlined here. In this regard, the trend of companies listed on the Johannesburg Stock Exchange (JSE) has been observed closely for this study. That is, as listing on the JSE is onerous, companies that are listed on its main board for more than 20 years are considered to have shown maturity thereby withstanding the everchanging business and economic dynamics and related regulations, hence are classified as value companies. On the other hand, and together with preliminary scrutiny by authors of the current study, companies that have only listed since 2006 may be classified as 'growth' as they exhibit features in contrast to those of value companies that is, they seem to pursue growth opportunities aggressively and do not prioritise paying dividends. The listing referred to here is of the main board of JSE as transfers from JSE's AltX listing or directly from non-listing.

The overall purpose of this study is to test and confirm whether, in a South African case, value companies pay high fraction of earnings as dividends, consistently have lower growth rates and do not pursue investments aggressively as do growth companies. This is the test of dividend life-cycle hypothesis. This study advances the work of Fama and French (2001), Grullon et al. (2002), DeAngelo et al. (2006), Brockman and Unlu (2011) and Coulton and Ruddock (2011), who all extend the pioneering work of corporate lifecycle hypothesis by Mueller (1972) and all are carried out in the developed markets. These studies find the relationship between companies' life cycles and dividend payout. Fama and French (2001) and Grullon et al. (2002) indicated that profitability, investment opportunities and size affect payout decisions. In particular, they note that large and more mature companies are more likely to pay dividends than those with more investments. DeAngelo et al. (2006) observed that companies with low retained earnings as ratio of total equity (RETE) tend to have more investment sets than those with high RETE. Amongst the independent variables that they identified, they also recognised RETE and RETA as key variables for dividend life-cycle hypothesis as they measure the extent to which companies rely on internal or external finance. Brockman and Unlu (2011) and Coulton and Ruddock (2011) reported results that are consistent 
with Fama and French (2001), Grullon et al. (2002) and DeAngelo et al. (2006).

This study seeks to, amongst others, test the dividend life-cycle hypothesis in South Africa, an emerging market economy to confirm whether its corporate payout policy, in this regard mirrors that of developed markets. The proxies for financial performance are economic value added (EVA) and return on assets (ROA), and other independent variables are size of company (SIZE), RETE, ROA, EVA and change in total assets $(\triangle \mathrm{TA})$. In line with the above-mentioned studies, this study adopts dividends $\left(\operatorname{Div}_{\mathrm{it}}\right)$ as dependent variable. This study lags dividends and EVA by 1 year to minimise the problem of endogeneity. In addition, lagged RETE and lagged EVA are also included as further independent variables. The essence of the relationship between dependent and independent variables in this study is that company's various stages in its life cycle influence its payout decisions.

\section{Research design and methodology}

From the given discussion, the following hypotheses are derived:

- Hypothesis 1 (H1): The change in assets $(\Delta \mathrm{TA})$ is positively correlated with current $\operatorname{Div}_{\mathrm{it}}$.

- Hypothesis 2 (H2): The ratio of RETE is positively correlated with current $\mathrm{Div}_{\mathrm{it}}$.

- Hypothesis 3 (H3): The ROA is correlated with current $\operatorname{Div}_{\text {it }}$.

- Hypothesis 4 (H4): SIZE is positively correlated with current $\operatorname{Div}_{\text {it }}$.

- Hypothesis 5 (H5): EVA is positively correlated with current $\operatorname{Div}_{\mathrm{it}}$.

The following regression model is derived from the given discussion in line with stated hypotheses:

$\operatorname{Div}_{\mathrm{it}}=\alpha_{\mathrm{i}}+\beta_{1}\left(\mathrm{SIZE}_{\mathrm{it}}\right)+\beta_{2}\left(\operatorname{RETE}_{\mathrm{it}}\right)+\beta_{3}\left(\operatorname{RETE}_{\mathrm{it}-1}\right)+\beta_{4}\left(\mathrm{ROA}_{\mathrm{it}}\right)+$ $\beta_{5}\left(\mathrm{EVA}_{\mathrm{it}}\right)+\beta_{6}\left(\mathrm{EVA}_{\mathrm{it}-1}\right)+\beta_{7}\left(\Delta \mathrm{TA}_{\mathrm{it}}\right)+\varepsilon_{\mathrm{it}}$ [Eqn1]

Where:

- $\operatorname{Div}_{\mathrm{it}}$ is dividend per share for company $i$ in period $t$

- RETE $_{\mathrm{it}}$ is ratio of retained earnings to total equity for company $i$ in period $t$

- $\mathrm{RETE}_{\mathrm{it}-1}$ is lagged ratio of retained earnings to total equity for company $i$ in period $t$

- $\mathrm{ROA}_{\mathrm{it}}$ is ROA for company $i$ in period $t$

- $\Delta \mathrm{TA}_{\mathrm{it}}$ is growth rate in assets for company $i$ in period $t$

- SIZE $_{\mathrm{it}}$ is size of company $i$ in period $t$

- $\mathrm{EVA}_{\mathrm{it}}$ is EVA for company $i$ in period $t$

- EVA $_{\mathrm{it}-1}$ is lagged EVA for company $i$ in period $t$

- $\varepsilon_{\mathrm{it}}$ is the error term.

\section{Data sample and collection}

This study utilised secondary data. The data were drawn from the published financial statements of South African listed companies, which are stored by Identification of
Requirements for Enterprise Social Software (IRESS). IRESS is a financial information database that has been used in South Africa successfully for the past few decades by researchers and other professionals. Therefore, the database is reliable in providing financial information for both academics and practitioners. The sample companies are those listed, all sectors included, on the main board of JSE. The sample period is 10 years (2006-2015). The total number of companies included in the sample, that is, whose information could be reliably obtained from IRESS for this study were 119 (Panel 1). And after the distinction between value and growth companies, 86 (Panel 2) and 33 (Panel 3) companies were confirmed, respectively.

\section{Choice of panel data estimators}

Corporate finance research has largely used econometric data estimation procedures to run regressions in this regard. In capital structure and payout decisions, the widely used estimators have been the ordinary least square (OLS), fixed effects (FEs) and random effects (REs). These fundamental estimators have proven to be useful, although they generally lack capabilities to handle common errors, such as heterogeneity and endogeneity, which plague corporate finance research, particularly in the modelling of data. Thus, some advanced estimators are recommended in the literature to address these problems and they have proven to be robust. These include the generalised methods of moment (Diff GMM) of Arellano and Bond (1991), system generalised methods of moment (Sys GMM) of Blundell and Bond (1998) and the least square dummy variable correction (LSDVC) proposed by Bruno (2005). See Flannery and Hankins (2013) and Moyo (2016) for justified robustness of these estimators. Following Andres et al. (2009) and Andres et al. (2015) who used a combination of fundamental and dynamic estimators successfully, this study adopted a combination of OLS, Diff GMM and Sys GMM to test the regression models. The LSDVC is superior over these estimators as it is bias-correcting and capable of providing better coefficient estimation consistency in the presence of dynamics in data sets, and hence it is used to test for robustness of estimation (Flannery \& Hankins 2013; Moyo 2016). The data winsorisation technique is applied on all variables included in the data analyses at $1 \%$ and 99\% percentiles to manage the possible effects of data outliers. All data analyses are generated using the STATA programme.

\section{Results and discussion Description analysis}

Table 1 presents descriptive statistics for full sample companies (Panel 1) and their comparative Tables in 5 (value companies: Panel 2) and 6 (growth companies: Panel 3). The presentation of these tables is followed by their comparative discussion. 
The very high DPS number of observations for value companies (709) over the growth companies (167) confirms somewhat that paying dividends are not a priority for growth companies. The trend is the same for all independent variables as growth companies comprise mostly recently listed companies. This trend was to be expected as recently listed companies may not prioritise paying dividends and are generally fewer than value companies.

There is a trend here confirming the dominance of value companies over the growth companies in Panel 1. The SIZE mean is relatively similar for Panels 1 and 2, although the standard deviation (SD) for these panels shows different disparities amongst sample companies within, that is, 1.63 and 1.48, respectively. The SIZE mean confirms that sample companies in this regard are relatively younger. The accompanying SD (1.32) is the lowest of the panels suggesting that the lowest disparities exist amongst the sample companies, in this regard.

The RETE shows related trend for all panels in respect of mean and SD. The two serve, amongst others, as indicators of retentions of earnings in relation to total equity capital and total assets and hence the relatively, same trend. The $\Delta \mathrm{TA}$ has a mean of $0.1374,0.1315$ and $0.1736, \mathrm{SD}$ of $0.1428,0.1229$ and 0.2281 for Panels 1, 2 and 3, respectively. Panel 3, amongst the three panels shows the highest $\triangle \mathrm{TA}$ mean of 0.1736 as it comprises growth companies, but the highest SD showing the highest disparities within the sample.
The growth companies (Panel 3) are shown to be the highest earner of profits, but at the same time because of relative uncertainties inherent within them. Panel 3 also has the highest EVA mean and the SD. The highest profitability mean for both ROA and EVA accompanied by same trend of SD for growth companies suggests a possible aggressive pursuance of growth projects and higher volatility of earnings. The assets growth $(\Delta \mathrm{TA})$ mean corroborates this phenomenon.

\section{Regression analysis}

The regression results are presented in Table 2 to Table 4. The grouping of panels here follows that of the descriptive analysis. These tables present results of several independent variables in respect of explaining dividend life-cycle hypothesis in South Africa. The dependent variable is DPS and independents are the SIZE, RETE, L_RETE, $\triangle T A$, ROA, EVA and L_EVA. The OLS, Diff GMM, Sys GMM and LSDVC were used to perform the regressions. After the presentation of Table 2 to Table 4, a comparative discussion of dependent variable follows.

The Wald test and $R^{2}$ are satisfied for all Panels; thus, confirming that the model fits the data. The Sargan test is valid for all regression estimators. The test results of VIF and tolerance factor, although not included here, confirmed for all independent variables included in the analyses the null hypothesis in respect of the possible multicollinearity problem.

TABLE 1: Descriptive statistics for all variables of Panel 1: Full sample.

\begin{tabular}{|c|c|c|c|c|c|c|c|}
\hline Variables & Observations & Mean & SD & Min & Max & Skewness & Kurtosis \\
\hline DPS (Cents) & 1087 & 174.81 & 166.97 & 7.50 & 508.30 & 0.8282 & 2.3661 \\
\hline SIZE (log) & 1084 & 15.50 & 1.63 & 13.00 & 18.03 & 0.0052 & 1.8336 \\
\hline RETE (Ratio) & 1088 & 0.0954 & 0.0705 & -0.0174 & 0.2118 & 0.0659 & 2.0388 \\
\hline L_RETE & 1056 & 0.1064 & 0.0792 & -0.0115 & 0.2453 & 0.2456 & 2.0879 \\
\hline$\Delta T A$ (Ratio) & 1048 & 0.1374 & 0.1428 & -0.058 & 0.4268 & 0.6383 & 2.5914 \\
\hline ROA & 1091 & 13.0404 & 10.1646 & -1.13 & 31.37 & 0.3647 & 2.1099 \\
\hline EVA (Rands) & 1083 & 0.0023 & 0.2958 & -0.3183 & 0.2035 & -0.1764 & 3.2413 \\
\hline L_EVA & 1049 & 0.0257 & 0.3127 & -0.2814 & 0.1856 & -0.1427 & 3.2657 \\
\hline
\end{tabular}

DPS, Dividend per share; EVA, economic value added; RETE, Retained earnings as ratio of total equity; ROA, return on assets; SD, standard deviation; Min, minimum; Max, maximum.

TABLE 2: Regression results for the test of dividend life-cycle hypothesis and determining factors: Panel 1.

\begin{tabular}{|c|c|c|c|c|}
\hline Variables & OLS & Diff GMM & Sys GMM & LSDVC \\
\hline SIZE & $68.306(24.81)^{* * *}$ & $106.764(1.83)^{*}$ & $42.293(10.15)^{* * *}$ & $24.845(5.05)^{* * *}$ \\
\hline RETE & $-123.663(-1.01)$ & $-274.799(-0.67)$ & $-74.771(-0.56)$ & $-0.000(-2.50)^{* *}$ \\
\hline L_RETE & $-12.455(-0.17)$ & $34.399(0.14)$ & $-6.074(-0.12)$ & $-45.830(-1.04)$ \\
\hline$\triangle \mathrm{TA}$ & $-37.502(-1.09)$ & $-36.286(-0.64)$ & $27.563(1.10)$ & $31.004(0.94)$ \\
\hline ROA & $2.561(4.06)^{* * *}$ & $8.912(2.03)^{* *}$ & $2.316(2.72)^{* * *}$ & $2.43 \mathrm{E}+00(4.44) * * *$ \\
\hline EVA & $0.000035(2.77)^{* * *}$ & $-6.64 \mathrm{E}-06(-0.19)$ & $-5.48 \mathrm{E}-06(-1.96)^{* *}$ & $1.07 \mathrm{E}-05(2.65)^{* * *}$ \\
\hline L_EVA & $0.000035(2.60) * * *$ & $0.000022(0.87)$ & $-0.000013(-0.60)$ & $1.87 E-06(0.88)$ \\
\hline Observations & 834 & 599 & 721 & 721 \\
\hline Adjusted $R^{2}$ & 0.43 & - & - & - \\
\hline Chi-squared test & - & 34.23 & 353.66 & 245.12 \\
\hline Prob>Chi2 & - & 0.0000 & & 0.0001 \\
\hline Sargan test & - & $171.54(35)$ & $103.27(43)$ & - \\
\hline
\end{tabular}

Note: The bracketed values denote $t$-statistics, and accompanying values outside brackets show correlation coefficients between dependent and corresponding independent variables. Parentheses $* * *, * *, *$ on coefficient estimations are significant at $1 \%, 5 \%$ and $10 \%$, respectively.

Diff GMM, difference generalised methods of moment; EVA, economic value added; LSDVC, least square dummy variable correction; OLS, ordinary least square; RETE, Retained earnings as ratio of total equity; ROA, return on assets; Sys GMM, system generalised methods of moment. 
TABLE 3: Regression results for the test of dividend life-cycle hypothesis and determining factors: Panel 2.

\begin{tabular}{|c|c|c|c|c|}
\hline Variables & OLS & Diff GMM & Sys GMM & LSDVC \\
\hline SIZE & $5.430(20.43)^{* * *}$ & $111.812(1.82)^{*}$ & $55.959(5.60)^{* * *}$ & $32.808(4.70)^{* * *}$ \\
\hline RETE & $-126.586(-0.89)$ & $-323.547(-0.75)$ & $-55.880(-0.36)$ & $-210.619(-2.26) * *$ \\
\hline L_RETE & $-59.707(-0.68)$ & $59.027(0.21)$ & $5.022(0.07)$ & $-66.336(-1.04)$ \\
\hline$\triangle \mathrm{TA}$ & $-23.992(-0.49)$ & $-17.379(-0.22)$ & $44.296(1.24)$ & $54.442(1.37)$ \\
\hline ROA & $3.074(3.45)^{* * *}$ & $8.878(1.98)^{* *}$ & $2.725(2.35)^{* *}$ & $2.706(3.56)^{* * *}$ \\
\hline EVA & $0.000022(1.78)^{* *}$ & $4.92 \mathrm{E}-06(1.77)^{*}$ & $-3.02 \mathrm{E}-06(-1.67) *$ & $7.83 \mathrm{E}-06(1.95)^{* *}$ \\
\hline L_EVA & $0.000037(2.77) * * *$ & $0.000021(0.87)$ & $-0.000011(-1.74)^{*}$ & $1.20 \mathrm{E}-06(1.80)^{*}$ \\
\hline Obs & 695 & 511 & 600 & 600 \\
\hline Adjusted $R^{2}$ & 0.37 & - & - & - \\
\hline Chi-squared test & - & 31.96 & 234.14 & 23.18 \\
\hline Prob $>\mathrm{Chi}^{2}$ & - & 0.0002 & 0.0000 & 0.0000 \\
\hline Sargan test & - & 154.77 (35) & $106.03(43)$ & - \\
\hline
\end{tabular}

Note: The bracketed values denote $t$-statistics, and accompanying values outside brackets show correlation coefficients between dependent and corresponding independent variables. Parentheses ***,**,* on coefficient estimations are significant at $1 \%, 5 \%$ and $10 \%$, respectively.

Diff GMM, difference generalised methods of moment; EVA, economic value added; LSDVC, least square dummy variable correction; OLS, ordinary least square; RETE, Retained earnings as ratio of total equity; ROA, return on assets; Sys GMM, system generalised methods of moment.

TABLE 4: Regression results for the test of dividend life-cycle hypothesis and determining factors: Panel 3.

\begin{tabular}{|c|c|c|c|c|}
\hline Variables & OLS & Diff GMM & Sys GMM & LSDVC \\
\hline SIZE & $20.751(12.46) * * *$ & $27.684(1.94)^{* *}$ & $16.211(4.53)^{* * *}$ & $0.042(0.18)$ \\
\hline RETE & $-257.893(-2.78) * * *$ & $-776.324(-1.71)^{*}$ & $-183.313(-2.34)^{* *}$ & $-60.149(-1.21)$ \\
\hline L_RETE & $-1.311(-0.04)$ & $39.222(0.44)$ & $37.895(1.91)^{*}$ & $22.772(1.13)$ \\
\hline$\triangle \mathrm{TA}$ & $-1.050(-0.09)$ & $-3.050(-0.28)$ & $-2.910(-0.45)$ & $5.240(0.87)$ \\
\hline ROA & $1.035(3.18)^{* * *}$ & $3.052(2.40)^{* *}$ & $0.584(2.03)^{* *}$ & $0.085(0.72)$ \\
\hline EVA & $0.000075(2.51)^{* * *}$ & $0.000091(5.47)^{* * *}$ & $0.000063(5.26)^{* * *}$ & $0.000072(6.59)^{* * *}$ \\
\hline Obs & 139 & 88 & 121 & 121 \\
\hline Adjusted $R^{2}$ & 0.67 & - & - & - \\
\hline Chi-squared test & - & 3200.06 & 460.53 & 27.06 \\
\hline Prob $>\mathrm{Chi}^{2}$ & - & 0.0000 & 0.0000 & 0.0010 \\
\hline Sargan test & - & $81.96(28)$ & $74.33(35)$ & \\
\hline
\end{tabular}

Note: The bracketed values denote $t$-statistics, and accompanying values outside brackets show correlation coefficients between dependent and corresponding independent variables. Parentheses $* * *, * *, *$ on coefficient estimations are significant at $1 \%, 5 \%$ and $10 \%$, respectively.

Diff GMM, difference generalised methods of moment; EVA, economic value added; LSDVC, least square dummy variable correction; OLS, ordinary least square; RETE, Retained earnings as ratio of total equity; ROA, return on assets; Sys GMM, system generalised methods of moment.

All model estimators show a positive correlation between SIZE and company's propensity to pay dividends $\left(\mathrm{Div}_{\text {it }}\right.$ for all panels. The correlation is significant for OLS and Sys GMM estimators. Hypothesis 4 is thus accepted. This suggests that the size of a company is a key determinant of company's decisions to pay dividends.

The RETE is negatively correlated with $\mathrm{Div}_{\text {it }}$ for all panels and the correlation is robust. This association confirms that indeed dividends are a residue of investments opportunities and more so for growth companies (Panel 3). Hypothesis 2 is rejected particularly for growth companies (see Panel 3) as they portray persuasive features in respect of endeavours for growth. These results are consistent with the predictions of free cash flow hypothesis and residual theory. The L_RETE shows a relative negative correlation particularly for Panels 2 and 3; this was to be expected as these panels present disaggregated results for value and growth companies, respectively, wherein we expect to observe real trends of companies that share relatively common features. This observed trend is in line with the propositions of Lintner (1956), which is further substantiated by Fama and Babiak (1968). As noticed by Andres et al. (2009), this trend is still observed in the modern dynamic data setting where unique institutional and regulatory environment play some key role. This means, lagged earnings influence payout decisions.
The $\Delta \mathrm{TA}$ has a negative, but insignificant correlation with $\operatorname{Div}_{\mathrm{it}}$. This somehow indicates that companies that prioritise growth over other key matters pay less dividends. Panel 3 shows most estimators with a negative sign over Panels 1 and 2, thus confirming the predicted and observed inferences. It was expected, therefore that growth companies (Panel 3) would prioritise growth over paying dividends. Hypothesis 1 is thus accepted as there is no evidence to the contrary. The results support those of previous pioneering researchers, notably Fama and French (2001), DeAngelo et al. (2006) and Coulton and Ruddock (2011) and other studies, namely Flavin and O'Connor (2017) and Bhattacharya et al. (2019).

Profitability as measured by ROA and EVA is significantly and positively correlated with Div $_{\text {it }}$. This was to be expected, as increased profits enhance company's ability to pay dividends. The correlation of SIZE and ROA with Div it is the same. Hypothesis 3 is accepted. This is not surprising as larger and more profitable companies are expected to pay more dividends. The EVA has a unique association with $\operatorname{Div}_{\text {it' }^{\prime}}$ that is, it shows a significant and positive correlation as shown by all estimators in relatively all panels. This trend is in line with that of descriptive analysis (see comparative Table 5 and Table 6), which shows a much higher EVA mean for growth companies. This finding 
TABLE 5: Descriptive statistics for all variables of Panel 2: Value companies.

\begin{tabular}{|c|c|c|c|c|c|c|c|}
\hline Variables & Observations & Mean & SD & Min & Max & Skewness & Kurtosis \\
\hline DPS (Cents) & 844 & 211.81 & 179.47 & 20.40 & 573.75 & 0.7988 & 2.4211 \\
\hline SIZE (log) & 840 & 15.96 & 1.48 & 13.67 & 18.28 & 0.0230 & 1.8695 \\
\hline RETE (Ratio) & 843 & 0.0981 & 0.0708 & -0.0155 & 0.2141 & 0.0364 & 2.0410 \\
\hline L_RETE & 842 & 0.1110 & 0.0808 & -0.0086 & 0.2527 & 0.2446 & 2.0977 \\
\hline$\Delta T A$ (Ratio) & 842 & 0.1315 & 0.1229 & -0.0402 & 0.3619 & 0.4341 & 2.2316 \\
\hline ROA & 845 & 12.1597 & 9.1513 & -1.0500 & 28.1000 & 0.2862 & 2.0704 \\
\hline EVA (Rands) & 844 & 0.076 & 0.3253 & -0.3057 & 0.1973 & -0.0432 & 2.9624 \\
\hline L_EVA & 841 & 0.0573 & 0.4635 & -0.2936 & 0.1898 & -0.0543 & 3.0021 \\
\hline
\end{tabular}

EVA, economic value added; RETE, Retained earnings as ratio of total equity; ROA, return on assets; SD, standard deviation.

TABLE 6: Descriptive statistics for all variables of Panel 3: Growth companies.

\begin{tabular}{|c|c|c|c|c|c|c|c|}
\hline Variables & Observations & Mean & SD & Min & Max & Skewness & Kurtosis \\
\hline DPS (Cents) & 243 & 33.34 & 41.00 & 2.98 & 125.00 & 1.3575 & 3.3016 \\
\hline SIZE (log) & 244 & 13.95 & 1.32 & 12.04 & 16.09 & 0.1928 & 1.8799 \\
\hline RETE (Ratio) & 245 & 0.0858 & 0.0689 & -0.0242 & 0.201 & 0.1405 & 2.0793 \\
\hline L_RETE & 214 & 0.0884 & 0.0723 & -0.0242 & 0.2132 & 0.2069 & 2.1011 \\
\hline$\Delta T A$ (Ratio) & 206 & 0.1736 & 0.2281 & -0.0762 & 0.6543 & 1.0695 & 2.9901 \\
\hline ROA & 246 & 16.2381 & 13.5035 & -2.16 & 39.51 & 0.3488 & 1.9880 \\
\hline L_EVA & 208 & 0.0056 & 0.3645 & -0.2167 & 0.1920 & -0.2001 & 3.2314 \\
\hline
\end{tabular}

EVA, economic value added; RETE, Retained earnings as ratio of total equity; ROA, return on assets; SD, standard deviation.

suggests the strength of growth companies over value companies in creating value for shareholders. Hypothesis 5 is accepted. These results seem to contradict those of previous researchers, amongst others, Crowther et al. (1998) and De Mortanges and Van Riel (2003). These researchers argue in favour of value companies as they recognise and emphasise distribution of dividends, company's ability and consistency in generating surplus cash. These attributes may not be associated with growth companies.

\section{Conclusion, implications and suggestions for future research}

The purpose of this study was to test the dividend life-cycle hypothesis in a South African case, an emerging economy. The test was extended amongst the three identified panel groups, namely Panel 1 (all sample companies), Panel 2 (Value companies) and Panel 3 (growth companies). The basis for adopting this grouping was to establish if there are differences or not amongst panels as to the prevalence of dividend life cycle. The sample comprises 119 companies (Panel 1), which were further divided between 86 value companies (Panel 2) and 33 growth (Panel 3) companies. The estimators, OLS, Diff GMM, Sys GMM and LSDVC were used to run regressions. The study suggests the prevalence of dividend life-cycle hypothesis amongst corporates in South Africa. It was found that SIZE, ROA and EVA have a positive and significant influence on a company's propensity to pay dividends $\left(\mathrm{Div}_{\mathrm{it}}\right)$. The correlation is especially robust for Panels 1 and 2, which are dominated by value companies, thus confirming the ability of these companies over growth companies (Panel 3) to pay dividends consistently. For Panel 3, only EVA has shown a significant relationship with dividend payments. This settles the strength of growth companies in creating value for shareholders. Growth in assets ( $\triangle \mathrm{TA}$ ) shows a negative, but insignificant correlation with $\operatorname{Div}_{\text {it }}$ particularly for growth companies. This statistic, although insignificant, is interpreted as indicating that indeed growth companies prioritise growth projects over paying dividends, a trend in line with the prevalence of dividend lifecycle hypothesis as noted by previous studies, amongst others, Fama and French (2001), DeAngelo et al. (2006) and Coulton and Ruddock (2011). These results have confirmed the South African corporate setting to be mirroring those of the developed economies, thus asserting the potential of financial managers at emerging economies to be well positioned to serve the interests of shareholders.

The study provided some implications for both financial managers and shareholders. For financial managers, the study confirmed, amongst them, firstly, the sacrifice of dividend payments to use earnings generated to pursue investment opportunities. Secondly and lastly, it is a unique finding for South Africa that growth companies can create more value for shareholders than value companies. These are enhanced decision alternatives for financial managers in their endeavours to create and maximise value for shareholders, particularly in emerging market setting. In respect to the interests of shareholders, evidence notes some noteworthy trends for South African corporate in respect of maximising value, notably, the finding that 'growth' companies seem to show potential to create more value than 'value' companies. This evidence should encourage shareholders not to undermine the value-creating prowess of growth companies.

Based on the empirical findings and some limitations inherent in this study, several suggestions are made in respect to future research in a relatively same area. Firstly, the study only concentrated on listed companies and this brought with it the survivorship bias. That is, possible inclusion of non-listed companies would have had their phenomenon fairly represented and enhancing sample sizes, and hence results of this study should be interpreted in this 
context. Nonetheless, it is submitted that fair representation of excluded companies may exist in either categories used in major parts of this study, that is, 'value' and 'growth' companies. Secondly and lastly, to the authors' knowledge, research is very minimal, if any, in respect to test of dividend life-cycle hypothesis for an emerging market setting and hence it is hereby recommended that further attempts be carried out in this regard to add to existing literature.

\section{Acknowledgements}

The main author, N.F.M., would like to thank his employer, University of Venda for providing environment conducive for PhD study which led to this article.

\section{Competing interests}

The authors declare that they have no financial or personal relationship(s), which may have inappropriately influenced them in writing this article.

\section{Authors' contributions}

N.F.M. is the main author of this article, H.W. and J.H. are second and third authors respectively.

\section{Ethical considerations}

This article complies with all ethical requirements for research without contact with animals and human beings.

\section{Funding information}

This research received not specific grant from any funding agency in the public, commercial or not-for-profit sectors.

\section{Data availability}

Raw or related data for this research are available on request from the corresponding author (N.F.M.).

\section{Disclaimer}

The views and opinions expressed in this article are those of the authors and do not necessarily reflect the official policy or position of any affiliated agency of the authors.

\section{References}

Ahmed, H. \& Javid, A.Y., 2008, Dynamics and determinants of dividend policy in Pakistan: Evidence from Karachi stock exchange non-financial listed firms: 148-171, Working paper, viewed 31 July 2018, from https://mpra.ub.unimuenchen.de/37342/1/MPRA_paper_37342.pdf.

Anda, J., Ikenberry, D., McVey, H., Nayar, A. \& Smith, C., 2005, 'Morgan Stanley roundtable on capital structure and payout policy', Journal of Applied Corporate Finance 17(1), 36-54. https://doi.org/10.1111/j.1745-6622.2005.023_1.x

Andres, C., Betzer, A., Goergen, M. \& Renneboog, L., 2009, 'Dividend policy of German firms: A panel data analysis of partial adjustment models', Journal of Empirical Finance 16(2), 175-187. https://doi.org/10.1016/j.jempfin.2008.08.002

Andres, C., Doumet, M., Fernau, E. \& Theissen, E., 2015, 'The Lintner model revisited: Dividends versus total payouts', Journal of Banking \& Finance 55(2015), 56-69. https://doi.org/10.1016/j.jbankfin.2015.01.005

Arellano, M. \& Bond, S., 1991, 'Some tests of specification for panel data: Monte Carlo evidence and an application to employment equations', Review of Economic Studies 58(2), 277-297. https://doi.org/10.2307/2297968
Ascioglu, A., Hegde, S.P. \& McDermott, J.B., 2008, 'Information asymmetry and investment-cash flow sensitivity', Journal of Banking \& Finance 32(6), 1036-1048. https://doi.org/10.1016/j.jbankfin.2007.09.018

Baker, M. \& Wurgler, J., 2004, 'A catering theory of dividends', Journal of Finance 59(3), 1125-1165. https://doi.org/10.1111/j.1540-6261.2004.00658.x

Banyi, M.L. \& Kahle, K.M., 2014, 'Declining propensity to pay? A re-examination of the life-cycle theory', Journal of Corporate Finance 27(2014), 345-366. https://doi. org/10.1016/j.jcorpfin.2014.06.001

Barclay, M.J. \& Smith, C.W., 2005, 'The capital structure puzzle: The evidence revisited', Journal of Applied Corporate Finance 17(1), 8-17. https://doi.org/10. $1111 / \mathrm{j} .1745-6622.2005 .0122 . x$

Bhattacharya, D., Chang, C.W. \& Li, W.H., 2019, 'Stages of firm life cycle, transition, and dividend policy', Finance Research Letters 33, 101226. https://doi.org/10.1016/j. frl.2019.06.024

Bhattacharya, S., 1979, 'Imperfect information, dividend policy, and "the bird in the hand" fallacy', Bell Journal of Economics 10(1), 259-270. https://doi.org/ $10.2307 / 3003330$

Blundell, R. \& Bond, S., 1998, 'Initial conditions and moment restrictions in dynamic panel data models', Journal of Econometrics 87(1), 115-143. https://doi. org/10.1016/S0304-4076(98)00009-8

Brockman, P. \& Unlu, E., 2011, 'Earned/contributed capital, dividend policy, and disclosure quality: An international study', Journal of Banking and Finance 35 (2011), 1610-1625. https://doi.org/10.1016/j.jbankfin.2010.11.014

Bruno, G.S.F., 2005, 'Approximating the bias of the LSDV estimator for dynamic unbalanced panel data models', Economics Letters 87(3), 361-366. https://doi. org/10.1016/j.econlet.2005.01.005

Coulton, J.J. \& Ruddock, C., 2011, 'Corporate payout policy and test of the life-cycle theory', Accounting and Finance 51(2), 381-407. https://doi.org/10.1111/j. 1467-629X.2010.00356.x

Crowther, D., Davies, M.L. \& Cooper, S.M., 1998, 'Evaluating corporate performance: A critique of economic value added', Journal of Applied Accounting Research 4(2), 3-34.

DeAngelo, H., DeAngelo, L. \& Stulz, L., 2006, 'Dividend policy and the earned/ contributed capital mix: A test of the life-cycle theory', Journal of Financia Economics 81(2), 227-254. https://doi.org/10.1016/j.jineco.2005.07.005

De Mortanges, C., \& Van Riel, A., 2003, 'Brand equity and shareholder value', European Management Journal 21(4), 521-527. https://doi.org/10.1016/S02632373(03)00076-8

Erasmus, P., 2013, 'The influence of dividend yield and dividend stability on share returns: Implications for dividend policy formulation', Journal of Economic and Financial Sciences 6(1), 13-31. https://doi.org/10.4102/jef.v6i1.274

Fama, E.F. \& Babiak, H., 1968, 'Dividend policy: An empirical analysis', Journal of the American Statistical Association 63(324), 1132-1161. https://doi.org/10.1080/01 American Statistical Associd

Fama, E.F. \& French, K.R., 2001, 'Disappearing dividends: Changing firm characteristics or lower propensity to pay?', Journal of Financial Economics 60(1), 3-43. https:// doi.org/10.1016/S0304-405X(01)00038-1

Flannery, M.J. \& Hankins, K.W., 2013, 'Estimating dynamic panel models in corporate finance', Journal of Corporate Finance 19(2013), 1-19. https://doi.org/10.1016/j. jcorpfin.2012.09.004

Flavin, T. \& O'Connor, T., 2017, 'Reputation building and the life-cycle model of dividends', Pacific-Basin Finance Journal 46(Part A), 177-190. https://doi. org/10.1016/j.pacfin.2017.09.006

Grullon, G., Michaely, R., Benartzi, S. \& Thaler, R.H., 2005, 'Dividend changes do not signal changes in future profitability', The Journal of Business 78(5), 1659-1682. https://doi.org/10.1086/431438

Grullon, G., Michaely, R. \& Swaminathan, B., 2002, 'Are dividend changes a sign of firm maturity?', Journal of Business 75(3), 387-424. https://doi.org/10.1086/339889

Harris, M. \& Raviv, A., 1991, 'The theory of capital structure', Journal of Finance 46(1), 297-355. https://doi.org/10.1111/j.1540-6261.1991.tb03753.x

Hu, F. \& Chen, X., 2012, 'Dividend smoothing and firm value: Evidence from Chinese firms', Proceedings of the International Conference on Information Management, Innovation Management and Industrial Engineering, 3, pp. 98-101, 20th-21st October, Sanya.

Jensen, M.C., \& Meckling, W.H., 1976, 'Theory of the firm: Managerial behavior, agency costs, and ownership structure', Journal of Financial Economics 3(4), 78-79. https://doi.org/10.1016/0304-405X(76)90026-X

John, K. \& Williams, J., 1985, 'Dividends, dilution, and taxes: A signalling equilibrium', Journal of Finance 40(4), 1053-1070. https://doi.org/10.1111/j.1540-6261.1985. tb02363.x

Leary, M.T. \& Michaely, R., 2011, 'Determinants of dividend smoothing: Empirical evidence', Review of Financial Studies 24(10), 3197-3249. https://doi. evidence', Review of
org/10.1093/rfs/hhr072

Lintner, J., 1956, 'Distribution of incomes of corporations among dividends, retained earnings, and taxes', American Economic Review 46(2), 97-113.

Marsh, T.A. \& Merton, R.C., 1987, 'Dividend behaviour for the aggregate stock market', Journal of Business 60(1), 1-40. https://doi.org/10.1086/296383

Miller, M.H., \& Modigliani, F., 1961, 'Dividend policy, growth, and the valuation of shares', Journal of Business 34(4), 411-433. https://doi.org/10.1086/294442

Miller, M.H., \& Rock, K., 1985, 'Dividend policy under asymmetric information', Journal of Finance 40(4), 1031-1051. https://doi.org/10.1111/j.1540-6261.1985. tb02362.x 
Moyo, V., 2016, 'Dynamic capital structure adjustment: Which estimator yields consistent and efficient estimates?', Journal of Economic and Financial Sciences 9(1), 209-227. https://doi.org/10.4102/jef.v9i1.38

Mueller, D.C., 1972, 'A life-cycle theory of the Firm', Journal of Industrial Economics 20(3), 199-219. https://doi.org/10.2307/2098055

Myers, S.C., 1984, 'The capital structure puzzle', The Journal of Finance 39(3) 574-592. https://doi.org/10.1111/j.1540-6261.1984.tb03646.x

Myers, S.C. \& Majluf, N.S., 1984, 'Corporate financing and investment decisions when firms have information that investors do not have', Journal of Financial Economics 13(2), 87-221. https://doi.org/10.1016/0304-405X(84)90023-0
Nworji, I.D., Adebayo, O. \& David, A.O., 2011, 'Corporate governance and bank failure in Nigeria: Issues, challenges and opportunities', Research Journal of Finance and Accounting 2(2), 1-19.

Rajagopalan, N. \& Zhang, Y., 2009, 'Recurring failures in corporate governance: A global disease?', Business Horizons 52(6), 545-552. https://doi.org/10.1016/j. bushor.2009.06.007

Rossouw, J. \& Styan, J., 2019, 'Steinhoff collapse: A failure of corporate governance', International Review of Applied Economics 33(1), 163-170.

Viviers, S., Firer, C. \& Muller, C., 2013, 'A review of the dividend payments of South African listed companies during the period 1977-2011', Management Dynamics 22(4), 2-19. 